TURIZAM

Volume 16 , Issue 2

40-49 (2012)

\title{
Marginalization of the Tharu Ethnic Group in Tourism Development in Nepal
}

\author{
Suman Pandit* \\ Received: October 2011 | Accepted: April 2012
}

\begin{abstract}
The main objective of this study is to analyze how the tourism development has marginalized the Tharu, an indigenous and ethnic group in the Terai region of Nepal. The research for this study was carried out in Chitwan National Park in Nepal, where the Tharu has been residing for a long time. The research work was based on the key informant interviews, participant observation and an analysis of secondary data taken from a variety of sources.

The study reveals that the expansion of tourism has led to social differentiation developing between the Tharu and the hill migrants, as most of the business activities in the area are controlled by the hill migrants, while the Tharu have been marginalized. The study also shows that tourism has empowered the hill migrant women more than the Tharu women; as both the group women previously used to depend on their husband's finances but now the hill migrant women are more financially independent.
\end{abstract}

Key words: Tourism Development, Marginalization, Tharu, Hill Migrants, Chitwan National Park, Sauraha, Nepal

\section{Introduction}

Tourism is important and is a key industry for the development of Nepal (Thapa, 2003). Nepal has a lot of potential for tourism development. It is an unique destination for trekking and hiking because of its unbeatable combination of natural beauty and cultural heritage. Nepal nestles among the world's highest mountains, including Mount Everest, and is the birthplace of the Lord Buddha. In addition, ten sites in Nepal have been designated as World Heritage Sites as declared by UNESCO, adding to the appeal for tourists. Among them, two sites are national parks, including Chitwan National Park. Tourism is an important source of foreign exchange and also can potentially contribute to the national balance of payments and act as a major source of income and employment. Throughout the world, the most compelling reason for pursuing tourism as a development strategy is its alleged positive contribution to the local or national economy (Sharpley, 2004). Government of Nepal has been

* National Planning Commission Secretariat, Nepal. Corresponding Address: GPOBOX: 9830, Kathmandu, Nepal. E-mail:suman0315@yahoo.com 
implementing different national plans regarding tourism development to uplift national and local economy.

The National Parks and Wildlife Conservation (NPWC) Act was passed in I973, leading to the establishment of Chitwan National Park, the first national park in Nepal. After the establishment of Chitwan National Park in 1973, it was added to the wildlife tourism itinerary. According to Timilsina (2007), Chitwan National Park is famous for its biodiversity in terms of flora and fauna, plus for its outstanding natural features. Wildlife tourism is increasingly viewed as an option to be used to justify the setting up of protected areas, particularly, in developing countries (Curry et al., 2OOI). Tourism is based on specifically wildlife viewing in Chitwan National Park. Given that Chitwan National Park has great potential in terms of wildlife tourism; the country has adopted a tourism development strategy there.

Since the establishment of Chitwan National Park and its declaration as a World Heritage site in I984, it has become part of the "tourist gaze" (Urry, I992), and has attracted many domestic and foreign tourists. In the meantime, tourism development has pulled hill-based peoples away from the hilly regions of Nepal, and the Tharu have been displaced from their homeland due to the tourism development initiatives. Vandergeest (2003) argues that all development has the potential to cause displacement in line with various "push" and "pull" factors. According to Cukier (2004), tourism creates a multitude of employment opportunities in both the formal and informal sectors, and in this regard, tourism in Nepal has encouraged investors to invest in tourism businesses, creating employment opportunities since the establishment of the National Park. However, the Tharu community has not benefited that much in comparison to other hill dwelling migrants, as it has distributed power unequally and the Tharu have been marginalized. The Tharu are not able to compete with the hill migrants due to the unequal power relations that exist. The major tourism-related business activities are managed by the hill migrants rather than the Tharu, and as the hill migrants have more knowledge and are technically skilled, they have been able to gain higher positions. In contrast, the Tharu have found themselves working in lower positions due to their inferior economic power. As Beteille argues power plays an important role to maintain and reproduce of social stratification everywhere (Beteille, I977, cited in Huang, 2003). Therefore, this paper will analyze how the tourism development has marginalized the Tharu in touristic place of Nepal.

\section{Study Area}

This research was conducted in Sauraha which is the part of Bachhauli Village Development Committee (VDC) in Chitwan District, located in central part of Terai region of Nepal. The distance from Kathmandu to Sauraha is $165 \mathrm{~km}$. The total area of Bachhuali VDC is 23.96 sq.km and the total population of Bachhuali VDC is IO,443 that have I,872 households (CBS, 2OOI). Among them, the number of population of Tharu is 5, OI6 i.e $48 \%$ of total population. Sauraha is one of the main entrance gates that are very close proximity to the Chitwan National Park. Sauraha was declared buffer zone area of the Chitwan National Park in 1996. The total area of buffer zone area of the park is $750 \mathrm{sq} . \mathrm{km}$. After the establishment of Chitwan National Park in I973, Tharu residing inside the park were taken out and compelled to stay in the buffer zone area. Sauraha is the main tourist hub as it is the main entrance point 




Figure 1. Map of Research Site

Source: National Planning Commission Secretariat, GIS Section.

to the park. The main reason of tourists to visit the Chitwan National Park is for wildlife tourism. The park has 50 species of mammals, more than 500 species of birds, 49 species of reptiles and amphibians and I2O species of fish (Nakarmi, 2007). One-horned rhinoceros, wild boar, gharial crocodile are commonly sighted wild animals in the park. Chitwan National Park didn't take much time to become famous among tourists. After the malaria eradication in Terai and declaration of World Heritage Site, the place saw a massive influx of hill migrants for settlement and business in touristic place. As a result, most of the tourism businesses were concentrated in Sauraha.

\section{Study Methods}

Basically, the research has adopted two methods of data collection; documentary and field research methods. Documentary research method is applied to get the secondary data from the data that have been collected in the past by some researchers on the history of Chitwan National Park. Further, the study has collected demographic data from Central Bureau of Statistics (CBS). The data that I received from different sources provided basic understanding about the local people and locality of my research site.

Fieldwork for this research took place from November, 2009 to January, 2010 in Sauraha. Interviews of key informants were conducted with the local Tharu people and the hill migrants. When I talked with key informants, I crosschecked the information that I got from different books and literature journals on different aspects of local people and locality in order to verify the reliability of the information. Furthermore, participant observation as a method allows one to gather data by participating in the daily lives of local people, and 
I used this method to understand the everyday socio-economic life of the Tharu and the hill migrants at my research site.

\section{History of Tourism in Sauraha}

In I959, a I75 sq. km area of the Tikauli forest was declared a margakunja (deer sanctuary) and in 1963 the area south of the Rapti River was declared a gaindakunja (rhino sanctuary), which is now located on the edge of the Chitwan National Park (Jana, 2007). In I962, safari tourism was introduced in Chitwan National Park by the state, and tourists started landing on the small landing strip near Meghauli, which was constructed in I96I on the occasion of the visit of Queen Elizabeth from the UK (Muller-Boker, 1999). Before the establishment of Chitwan National Park in I973, infrastructure in the area was not well developed, as only the state elites and their counterparts visited the area to hunt wild animals and for recreation. Tourism in Chitwan National Park was started in 1962 by Mr. Copeman, the Director of Tiger Tops, who set up a four- bed tented camp.

The number of visitors to Chitwan National Park in 1974 was 836; however, this had reached 85,753 by the year 2007 . The number of tourists coming from foreign countries outweighs domestic tourists and those from South Asian Association for Regional Cooperation (SAARC) countries. Tourists come from Western countries mainly to observe the nature and wildlife of the National Park.

Table 1. Tourist Arrivals in Chitwan National Park (2002-2007)

\begin{tabular}{|l|r|r|r|r|r|r|}
\hline Tourist Type & \multicolumn{1}{|c|}{2002} & \multicolumn{1}{c|}{2003} & \multicolumn{1}{c|}{2004} & 2005 & 2006 & 2007 \\
\hline Nepalese & 12586 & 10826 & 9546 & 14977 & 24890 & 24906 \\
\hline Foreign & 29349 & 40096 & 30204 & 35838 & 51164 & 56888 \\
\hline SAARC & 6986 & 6954 & 2904 & 3580 & 5121 & 3959 \\
\hline Total & 48921 & 57876 & 42654 & 54395 & 81175 & 85753 \\
\hline
\end{tabular}

Source: District Profile of Chitwan, 2008.

There are now seven concessionaire hotels and three tented camps operating inside the Park, with a total of 492 beds available. Tourism has developed in the eastern, central and western sectors of the Park up to Amaltari. There are nine park entry gates that issue park entry permits to visitors all along the northern border; however, there is no tourism in the southern sector of the Park. The highest amount of tourism is in eastern sector of the Park, followed by the central and western sectors.

The first non-commercial lodge was built at Kasara in 1939 for the visit of King George VI of England. This lodge was the first building in the Terai to be made of concrete (Mishra \& Jefferies I99I, cited in Kunwar 2002). The first safari hotel opened in 1965, even before the National Park had been created, and there was only one simple lodge by 1977 in Sauraha. Tourism did not increase rapidly between 1980 and 1990 in Sauraha; however, after the restoration of democracy in Nepal in I990, tourism increased quickly. The total number of hotels, resorts and lodges is 70 at present in Sauraha, based on my interview with the Regional Hotel Association of Sauraha. The number of hotels and resorts has increased rapidly since i990. Prior to I994, most of the resorts were designed in line with the traditional Tharu hut - with thatched roofs, but since 1994 most of these have been replaced by concrete buildings, with the thatched roofs replaced by zinc plates. 
Tourism is very highly concentrated in the central sector of the Park in Sauraha, and several types of tourism activities are conducted there, the most popular being elephant rides ( $85 \%$ of tourists), followed by boating/canoeing at $80 \%$, jungle walks at $80 \%$ and jungle drives at $60 \%$.

\section{Tourism Development as an Employment Generator; Marginalization of the Tharu}

According to Kunwar (2OO2), the hotels and resorts in Sauraha signify a huge investment having taken place. Hotel owners claim that investment in hotels and resorts gave good returns in the past when there were not many hotels and resorts, and thus little competition among lodge owners. Competition is likely to increase even more in the future as a number of new resorts are under construction.

According to the Figure 2, the number of hotels and resorts owned by hill migrants is 60 or $86 \%$ of all those present; however, the number of hotels and resorts owned by members of the Tharu group is only seven, or IO\% of the total. Similarly, three hotels and resorts are operated by foreigners from Germany. This clearly shows that most of the hotels and resort businesses in the Park are controlled by hill migrants.

In the case of grocery shops in the area, most of the large and medium-sized shops are owned by hill migrants; however, the grocery shops owned by the Tharu tend to be small in comparison. I found two pharmacy shops which belong to hill migrants but none are run by the Tharu in Sauraha. Also, many travel and tour offices are operated by the hill migrants compare to the Tharu.

Similarly, most of the high standard, luxurious and high-end restaurants are owned by hill migrants, and also most of the handicraft and curio shops also. Hill migrants control the major businesses in Sauraha, whereas the Tharu have been left behind and are playing only a marginalized role in every income generating sector.

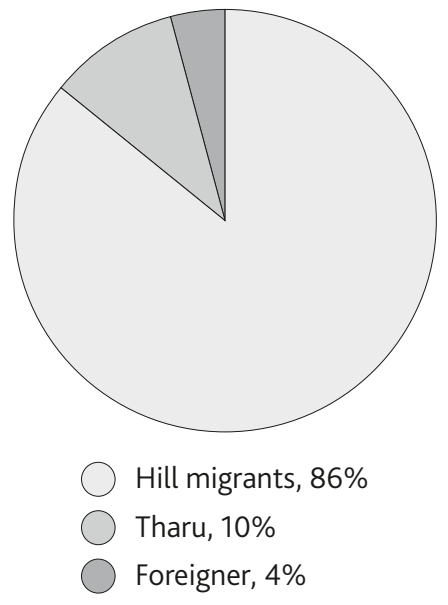

Figure 2. Percentage of Hotel \& Resorts Occupied

Source: Regional Hotel Association of Sauraha, 2009.

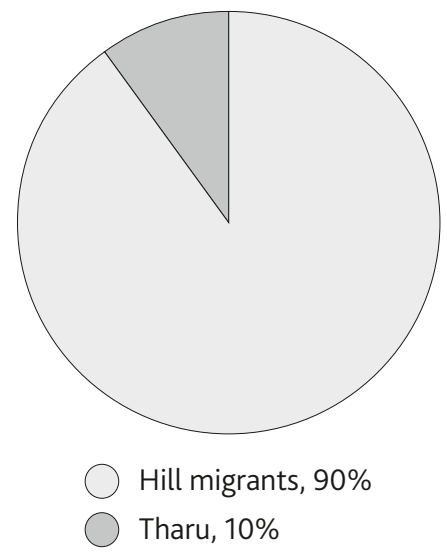

Figure 3. Percentage of Working in Managerial Position

Source: Field Interview, November, 2009.

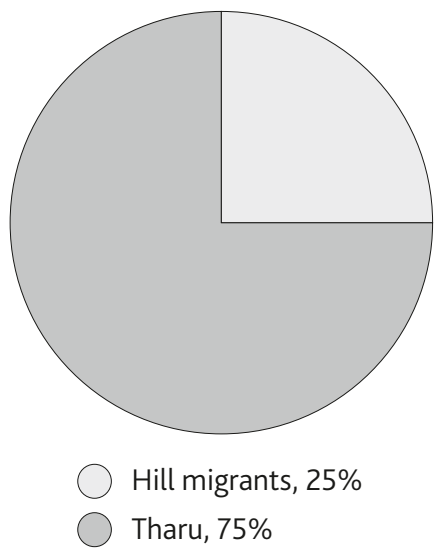

Figure 4. Percentage of Working in Lower Position

Source: Field Interview, November, 2009. 
As discussed above, nearly $86 \%$ of the hotels and resorts in Sauraha are operated by hill migrants, while only IO\% are owned by the Tharus. Overall, hotels and resorts have generated nearly I,30O to I,5OO direct jobs and many more indirectly. Figure 3 indicates that 90\% of managerial positions are occupied by hill migrants. During my field study, I found that most of the Tharu work as waiters, room boys, cooks and dish washers because the Tharu are generally less well educated and skilled than the hill migrants, meaning they work in lower positions and earn a lower salary. The hill migrants have a better knowledge of hotel management and are thus qualified for higher positions. For some of the top level positions, employees have been hired from Kathmandu and Pokhara. In total, there is a $25 \%$ and $75 \%$ split between the hill migrants and the Tharu respectively in term of their occupation of the lower level positions in the hotels and resorts of Sauraha.

The Tharu run many kinds of shop in Sauraha, such as small grocery shops, butcher's shops and small restaurants, but their businesses are not as well developed as the hill migrants'. The main problem is that they have not been able to invest the required amount of money in their businesses due to their weak financial condition. However, tourism has given them the opportunity to set up some small businesses; for example, I spoke to a poor Tharu man (Mr. CN) who had been displaced from the main tourist hub.

I am an original dweller here. I am married but I am not so educated and I only passed class two, but I am able to read and write. I am landless; I have no house of my own and have to rent. I have a small grocery shop, but I have no big amount of money to invest on a big shop. My condition is therefore very poor. I have two sons who are both studying. It is difficult to pay for tuition fees from my business earnings; I get only Rs. 5, OOO per month from this small grocery shop. It is very difficult to support my life with this amount. Generally, I wake up between 5 and 6 a.m., and open my shop at 7 a.m. In a day, I usually earn Rs. IOO to 200. My wife is illiterate and is a housewife. She looks after our house and cooks the food. She sometimes takes care of the shop if I am outside, as sometimes I work outside on others' agriculture land. I want my sons to have more of an education so their lives will not be like mine. I close the shop at 8 p.m. and we go to sleep at IO p.m (Interview: January 2OIO).

Mr. CN is a poor Tharu man who was displaced from the main tourist hub and has no land. Although he is an original dweller in the area, he was displaced from his own land and left landless. He now lives in a rented house and has a very small shop which earns only Nrs. IOO to 200 per day, making it very difficult for him to support his and his family's daily activities. This is why he sometimes has to work on a hill migrant's agricultural land. A social relationship exists between the hill migrants and the Tharu, as the hill migrants usually hire the Tharu to work for them in their fields, hotels, resorts and other businesses in Sauraha. This is a common situation in Sauraha; the Tharu are one of the main sources of labor for the hill migrants to work on their agricultural land and in their businesses.

Another fact I came across was that the jobs open for Tharu women are generally seasonal; from September to December and from January to May are the tourist seasons in Sauraha. Only some hotels and resorts provide permanent work, otherwise they are able to get jobs during the high season only. The Tharu women generally work as laundry maids, dish washers and room cleaners, while the Tharu men are engaged as room cleaners, room boys, cooks and waiters. Their salaries are very low when compared to their expectations. One Tharu worker told me that people who work in a managerial position can receive IO,OOO to I5,OOO Nepalese rupees a month, whereas those in lower positions make just 3,000 to 5,000 per month. Therefore, Tharu people tend to play safe by shifting from one hotel to another in search of a higher salary; they are not satisfied with the one they receive. One young Tharu 
man (Mr. DK - aged 2O) expressed his feelings about his job, in which he works as a waiter at a restaurant in Sauraha:

I am 20 years-old, am single and from the western part of Chitwan. I came here two years ago in search of a job. I did not get my SLC (School Leaving Certificate), as I gave up my studies while in class IO. Prior to this current job, I worked in one of the lodges in Sauraha but was not satisfied with the salary; they gave me just Rs. 2000 and food per month. I started at this restaurant three months ago, and it belongs to one of the hill migrants. Now I get Rs. 3,00O a month and tips from the tourists. I am more satisfied with my present job than the previous one. I had to give up my education because of my family's situation; my father has died and my mother is a housewife and is illiterate. Thus in response to my family's financial problems I joined this profession. I have three brothers; one is studying for a Bachelor's degree and another is working in Malaysia and has just finished class five. Sometimes, he sends money to my mother. My younger brother is studying in class IO. We have 2.5 bighas of land in my home town. Usually, my work at the restaurant starts early in the morning around 7 a.m. and lasts until 9 p.m. The restaurant business is best in the tourist season, and my income increases if I get tips from the tourists. My life is not so easy and I have to work hard. If I am able to earn more money in future I plan to open my own restaurant (Interview: December 2009).

I found that some of the Tharu from others parts of the Chitwan area have come to Sauraha in search of work at hotels and resorts. In the case of Mr. DK, he is from the western part of Chitwan and came to Sauraha two years in search of work. Previously, he worked in a lodge run by one of the hill migrants but shifted to a restaurant, which is also run by a hill migrant, in the expectation of receiving a higher salary. The Tharu frequently shift from one place to another in order to find a higher salary, as most are unskilled workers and so are forced into receiving low salaries from the hill migrants. I also found out that many of the Tharu have to give up their education in order to search for work, mainly due to their family's financial situation. In addition, the 'glamour' of the tourism industry attracts Tharu to this profession.

Similarly, I talked with one married Tharu woman who lives outside the main tourist hub (Mrs. SK) during my fieldwork. I talked about her family background and the family's occupations. She told me:

I am local, work as a housewife and am literate. My husband works as a tourist guide and he is also literate. I have one son and one daughter; we live in an extended family. My father-in-law is also literate and he works as a mahout. My mother-in-law is a housewife. We have no land, so we rent. We have to buy everything from market and have no means of agricultural production to support our livelihoods. We are poor and it is not so easy to support our lives. (Interview, January 2OIO).

In the case of Mrs. SK, I observed that she lives with an extended family and most of her family members have jobs. However, their income level is low and so they find it difficult to support their daily lives; moreover, they are landless and stay in a rented house which is in poor condition. Furthermore, I examined that Mrs. SK and her mother-in-law are confined in domesticity and caring their family.

Tourism has created investment opportunities for local people across different kinds of business. During my field work, I talked with an elderly hill migrant woman (Mrs. AM), who said:

I am 65 years old, illiterate and a Brahman. We migrated here from Gorkha District sixteen years ago. My husband works in India now - he is literate. Once a year, he comes here. I have only one daughter and I live with her. She has passed high school and has two daughters. One daughter is studying in class 8 and the other is in class 4. Both are studying at a boarding school. My daughter is a housewife and looks after her family. I have a grocery shop, but business is seasonal here. During the tourist season business is good, but off-season it is not so good. In the tourist season, my income 
is more than Rs. 20,000 per month. My daughter sometimes looks after the shop, and her husband has his own resort in Sauraha. He is a graduate from university and his income is good enough to support their life. Sometimes protests from different political parties create a problem for our business, as we have to shut down our shop. Usually I open the shop at 6 a.m. in summer and at 7 a.m. in winter. I close my shop at 8 p.m. Now, I am fully focused on the shop, as I have no extra land (Interview with an elderly woman: December 2009).

From my observations, Mrs. AM is fully able to sustain her family's economic needs as her husband works in India and she has a good business. Her daughter and son-in-law stay together with her in the same house; moreover, her son-in-law has his own resort in Sauraha. Mrs. AM's house is of a good design and is in the main tourist area where she can run her own shop. This all shows that her financial condition is strong and that she comes from a relatively wealthy background.

Mrs. AM told me that her business is sometimes adversely impacted by protests by various political parties, and this also creates problems for other businesses in Sauraha and is a common problem throughout the country. Business is seasonal in Sauraha and depends on tourists, so if the number of tourists is high, then business is good and incomes are high. Mrs. AM also mentioned that her income is high during the tourist season but low in the off season. Furthermore, I observed that development projects have changed the gender relations in Sauraha. In essence, Nepal is a male dominated society, with wives depending entirely on their husbands' incomes and with their general status being as housewives. However, Mrs. AM does not have to fully depend on her husband's income as she has her own grocery shop, which has helped increase their income and support their daily life activities.

I also talked with one of the hill migrant hotel owners' wives (Mrs. BN) during my fieldwork in Sauraha, during November 2009. She said she sometimes helps her husband with the hotel business:

I am Brahman and received my school leaving certificate. My husband migrated here from Gorkha District 35 years ago having completed a degree. We have two sons and one son has already passed his IO+2 and the next is studying for it. I have a hotel and a good grocery shop. My husband handles the hotel business, which is seasonal in nature. Our business depends on tourists and now the sector is very competitive; there are lots of hotel and resorts being established in Sauraha. Similarly, my grocery shop depends on tourists and that sector is also competitive nowadays. If business is good, I can earn up to Rs. 300,000 per month - enough to support our life. I have I.5 bighas of land - not so much, but others carry out agricultural production activities on that land on a contract basis. My life is very busy as I have to look after the house and grocery shop; I sometimes even help my husband with his hotel business. Our sons provide help with the management of the business also. I am therefore fully engaged from morning until night (Interview: November, 2009).

I observed that Mrs. BN's family is also financially strong and well educated, and she has her own hotel and grocery shop in the main tourist hub, so her income is very high and she has a lot of land. Tourism has made the daily lives of the people involved in this business very busy in Sauraha. Previously, women only used to work as housewives and care for the family, but recently the situation has changed drastically, as in case of Mrs. BN, who, due to being so busy, has little time to work on her agricultural land. As a result, she rents her land on a contract basis to a Tharu farmer, and in return receives a rental income. I also observed that in Mrs. BN's hotel, some Tharu people work in lower positions. Normally, the hill migrants recruit Tharu people into their hotels and resorts, restaurants and other businesses in lower positions, as in Nepalese society the Tharu are believed to be very kind, honest, and loyal ethnic and indigenous people. 
Tourism gives hill migrant families the opportunity to make their own money and support their families. In the case of the two hill migrants mentioned above, Mrs. AM and Mrs. $\mathrm{BN}$, they have their own grocery shops which are more developed than the Tharu's. In the case of the first lady, her husband works in India, while the second lady's husband has his own resort. In this regard, these women are helping their family to support their livelihoods, while in the case of the Tharu family i.e. Mrs. SK and Mr. CK, Tharu women are confined to domestic duties and caring for the family.

When comparing the cases of the two hill migrants Mrs. AM and Mrs. BN with the Tharu Mr. CN and Mrs. SK, it can be seen that the two hill migrants are very strong economically than Mr. CN and Mrs. SK, as Mrs. AM and Mr. BN have much higher incomes. Mrs. CN's wife and Mrs. SK is also only a housewife who looks after her children and cooks food. In the case of Mr.CK wife, she sometimes looks after their small shop when her husband is absent. However, the two hill migrants, Mrs. AM and Mrs. BN, manage grocery shops by themselves in addition to their involvement in domestic work.

\section{Conclusion}

Tourism has largely increased social differentiation between the hill migrants and the Tharu. Due to their limited economic power and skills, the Tharu cannot compete with the hill migrants in terms of work. The major tourism businesses in the area are controlled by the hill migrants, forcing the Tharu to play a marginal role in the touristic space, though the tourism business is booming in Sauraha. Due to the lack of essential qualifications and skills, the Tharu are forced to work in lower level positions to support their livelihoods.

Tourism has empowered the hill migrant women more than the Tharu women; as both the group women previously used to depend on their husband's finances but now the hill migrant women are more financially independent. Tourism has distributed power unequally in Sauraha, and this has led to the marginalization of the Tharu in their own homeland. However, it has led to social relations developing between the hill migrants and the Tharu, as the Tharu are often employed by the hill migrants on their commercial enterprises.

Tharu culture is one of the major attractions in Sauraha besides wild life tourism. If Tharu were displaced and continuously marginalized from their ancestral land, it would be harmful to develop ethnic tourism in Sauraha. It is also very important to preserve the Tharu's identity in Sauraha because it is an attractive place to view their culture .For the tourism development in Sauraha, the state should implement an empowerment program aimed at settling problems related to the Tharu by launching a special package to raise their social and economic status.

\section{References}

Beteille, A. (1977). Inequality Among Men. Oxford: Oxford University Press. CBS. (2OOI). Population Census. Kathmandu: Central Bureau of Statistics.

Cukier, J. (2004). Tourism Employment Issues in Developing Countries: Examples from Indonesia. In R. Sharpley \& D. J. Telfer (Eds.), Tourism and Development: Concepts and Issues: Channel view publications. 
Curry, B., Moore, W., Bauer, J., Cosgriff, K., \& Lipscombe, N. (2OOI). Modeling Impacts of Wildlife Tourism on Animal Communities: A Case Study from Royal Chitwan National Park, Nepal. Journal of Sustainable Tourism, 9(6), 5I4-529.

Huang, J. (20O3). Tourism in Tibetan Community: A Study on Social Differentation, Identity and Gender MA Thesis, Chiang Mai University, Chiang Mai.

Jana, S. (2007). Working Towards Environmental Justice: An indigenous Fishing Minorities Movement in Chitwan National Park, Nepal. Kathmandu: ICIMOD.

Kunwar, R. R. (20O2). Anthropology of Tourism: A Case Study of Chitwan, Sauraha. Delhi: Adroit Publishers.

Mishra, H. R., \& Jefferies, M. (I99I). Royal Chitwan National Park: Wildlife Heritage of Nepal. Kathmandu: King Mahendra Trust for Nature Conservation.

Muller-Boker, U. (I999). The Chitwan Tharus in Southern Nepal: An Ethnoecological (Translated by Philp Piarce). Stuttgart: Franz Steiner Verlag.

Nakarmi, G. (2007). Evaluation of Protected Areas: A Case Study of Chitwan National Park MSc Thesis, University of Klagenfurt, Austria.

Sharpley, R. (2004). Tourism: A Vehicle for Development? In R. Sharpley \& D. J. Telfer (Eds.), Tourism and Development: Concepts and Issues: Channel View Publications.

Thapa, B. (2003). Tourism in Nepal: Shangri-La's Troubled Times. In M. Hall, D. J. Timothy \& D. T. Duval (Eds.), Saftey and Security in Tourism: Relationships, Management and Marketing (pp. II7-I38): The Haworth Hospitality Press.

Timilsina, L. B. (2007). Contribution of Buffer Zone Management on Livelihood Support: A Case Study from Chitwan National Park, Nepal. M.Sc Thesis, University of Klagenfurt, Austria.

Urry, J. (1992). The Tourist Gaze: Sage Publications.

Vandergeest, P. (2003). Land to Some Titlers: Development-Induced Displacement in Laos International Social Journal, 55, 47-56. 